\title{
Automatic Blood Collection and Mixer in a Blood Transfusion System Equiped with Barrier Indicators
}

\author{
Chandra Bimantara Putra ${ }^{1}$, Her Gumiwang Ariswati ${ }^{1}$, Sumber ${ }^{1}$, Muzni Zahar ${ }^{2}$ \\ ${ }^{1}$ Department of Medical Electronics Engineering technology, Politeknik Kesehatan Kementerian Kesehatan Surabaya \\ Jl. Pucang Jajar Timur No. 10, Surabaya, 60245, Indonesia \\ ${ }^{2}$ Politeknik Caltex Riau \\ Jl. Umban Sari (Patin) No. 1, Rumbai, Umban Sari, Kec. Rumbai, Kota Pekanbaru, Riau 28265 \\ E-mail: Chandra.nusantara@yahoo.com
}

\begin{abstract}
Article Info
History Articles:

Receive Mei 15, 2020

Revised August 10, 2020

Received August 30, 2020

\section{Keywords:}

Blood Transfusion

Load Cell

HX-711

Arduino

Blood Bags

Abstract

A blood collection monitor is a device used to measure and shake the blood bag during a blood transfusion so that the blood in the bag does not clot and is mixed with anticoagulant fluid in the bag properly. This study aims to design an automatic blood collection and mixer for the transfusion blood system. The advantage of the proposed design is accompanied by a safety system in the form of a barrier indicator that is connected to an alarm. The alarm served to give a warning to blood donors if there is an obstacle or there is no increase in volume as much as $20 \mathrm{ml}$ for 1 minute as recommended by the world blood bank association. This device can work with three different sizes of blood bags. In this study, a loadcell sensor is used to detect the amount of blood fluid that enters the bag. Furthermore, then it is converted into milliliter volume. In order to collect the blood, a shaker is drove using a motor controlled by Arduino microcontroller. From the measurement, for the entire size of the blood bag, we found that the deviation is $0, \mathrm{UA}$ is 0 , and the average error is 0 . Thus, it can be concluded that this device can be used properly. In the future, it can be developed a blood infusion with the flowrate measurement to determine the speed of blood during donation.
\end{abstract}

This job open access articles and licensed under $\underline{\text { Creative }}$ Commons Attribution-Non-Commercial 4.0 License International,

\section{HER GUMIW ANG ARISTAWATI}

Department of Medical Electronics Engineering Technology

Politeknik Kesehatan Kementerian Kesehatan Surabaya

Jl. Pucang East Jajar No. 10, Surabaya, 60245, Indonesia

E-mail: Ariswatihergumiwang@gmail.com

\section{INTRODUCTION}

Blood transfusion is the process of transferring blood from one person (donor) into another person's blood vessels (recipient). This is done as an action to replace blood loss due to bleeding or to those who need it. At the time of the blood transfusion process, to anticipate the process of a blood clot so that blood can spread throughout the bag evenly, and make it easier for officers during the process of taking blood donors to the blood bag. It is hoped that there will be tools that help and facilitate the process of blood transfusion to prevent blood clots.

Blood collection mixer tool is a tool used to assist the implementation of blood donations in avoiding the process of blood clots or clots in blood bags that come from donors, by placing blood bags in blood bag containers. Then the container where the blood bag is shaken with the help of a motor that is in this tool [1]. The function of shaking the blood bag is so that the anticoagulant solution in the blood bag is mixed with blood from the donor. The solution in the bag is "Anticoagulant Citrate Phosphate and Dextrose Ademine Solution (CPDA-1)". This solution serves to prevent blood clots or (coagulation) from the donor as long as the blood is in the blood bag [2]. The tool works when the blood transfusion process takes place, blood bags that have been placed on the device, then in a mixer so that the blood entering the bag becomes homogeneous or the blood does not clot and can spread properly throughout the blood bag [3].

When the blood bag weight has reached the volume selection setting, the device will automatically stop the flow of blood in the blood bag tube. For the process of using a tool that is placing a blood bag with a size that has been chosen to place a blood bag on the device, and the blood bag tube is passed on 
a clamp on the device [4]. The volume of blood bags in general is not only one measure of the volume of blood bags but there are a number of different types of blood bags needed by $250 \mathrm{ml}$, $350 \mathrm{ml}$ and $450 \mathrm{ml}$.

In its application blood donors often also do not know if there is a disruption or blockage during the blood transfusion process so that the transfusion does not go well because there is an obstacle but is not known by blood donors, most blood donors when implementing the transfusion process they use this tool to make sure how much volume of blood you have in the bag. [5]. The Blood Collection Monitor tool generally also analyzes blood flow every second during the donation process. In accordance with the tool's instruction manual, flow rates during a transfusion can be categorized into three levels as follows: low flow, optimal flow, and high flow rate. "Low flow" indicates a flow rate of less than $10 \mathrm{~mL}$ every 30 seconds, whereas "high flow" is more than $90 \mathrm{~mL}$ every 30 seconds, and it is considered optimal when the flow rate is between $10 \mathrm{~mL}$ and $90 \mathrm{~mL}$ every 30 seconds [6]. A previous tool that has been made and developed by Santi lailatus solicah in 2016 proposed an automatic blood bag shaker. The device has been developed by adding several choices of setting bags, namely $250 \mathrm{ml}, 350$ $\mathrm{ml}$, and $450 \mathrm{ml}$. But the tool only shows the state when after the settings specified only with the LED light as an indicator. The tool also has a disadvantage that is the reading of the weighing sensor is not good because the movement of the motor shaker accompanies it, and the signal conditioning circuit is still not good. And there are weaknesses in the mechanical design that makes movement when the shaker less stable. In this case, the author will develop and refine the tool by adding a measurement selection method for three blood bag volume measurements, which is added to the LCD display to determine the stage for each addition of $10 \mathrm{ml}$ volume, the author also wants to develop a tool from the old software module namely using the Atmega 16 microcontroller with the latest software module, Arduino Atmega328. As well as providing an additional obstacle indicator with an alarm buzzer programmed automatically by Arduino that serves to provide a warning if during the blood transfusion process there are obstacles or disturbances, so as not to cause an increase in the volume of blood bags by $20 \mathrm{ml}$ for 1 minute indicating the blood does not flow with well, so that blood donors can take effective action to get good donor results [7] as recommended by the American Association of Blood Bank (AABB), which recommends the establishment of an automatic safety feature if the blood flow in the bag during donation is less than $20 \mathrm{ml}$ per minute or no more than 2 minutes. The guidelines are recommended for maintaining platelets and plasma or blood components for too long [6]. And the writer will correct the weaknesses of the shaker motor mechanical design by distinguishing the way the blood bag shakes and the method of taking sensor data, ie the writer will change the way the shaking of the device has been made by changing the location of the load cell sensor with a still or not moving position, which is expected reading data at the time of weighing is more maximal because the sensor will read in a stable state, and is expected to reduce the error value of the device that has been made previously.

In making this automatic blood collection mixer tool module, the writer raised the concept of a tool with a manufacturing tool that is with the brand CompoGuard Fresinius Kabi. A Blood Collection Monitor tool that the writer found when surveying directly to the blood donor site at the Blitar city PMI. There is also a safety system in the form of an obstacle indicator if there is an obstacle or disturbance during the blood transfusion process, the tool also becomes the author's reference if there is a manufacturer's blood collection monitor that has a buzzer alarm indicator if an obstacle occurs during a blood transfusion.

The author also made additional battery or battery resources as a substitute for the PLN power source when operating the equipment in a place where there was no electricity, and could be charged while being connected to the grid. If the previous device made by Santi Lailatus Sholicah in 2016 uses a battery only as a backup device but has not been equipped with a system to charge the battery at the same time when connected to a power line, it will help facilitate the process of blood transfusion when outside. a room or place where there is no electricity

\section{MATERIALS AND METHODS}

\section{A. Experimental Setup}

This study uses objects with blood fluid samples and load cell sensors. Data collection is carried out sequentially, starting from each increase of 10 milliliters. Data collection is 5 times for each increase of 50 milliliters.

\section{1) Materials and Tools}

This study uses a load cell sensor and HX-711 module as a detector for increasing volume. Components used as Arduino Uno Atmega 328 microcontroller sensor, LCD 2 x 16 as a display. And a DC servo motor to shake up blood bags.

\section{2) Trial}

In this study, the researchers measured the output of the loadcell voltage for every ten milliliters in the increase in the volume of the blood sample, using an meter to determine the increase in each voltage in the loadcell sensor, and in adjusting the results displayed with the incoming volume by comparing with the results, the liquid is inserted using an injection syringe, to determine the accuracy at each reading of $50 \mathrm{ml}$, up to 450 milliliters displayed on the LCD with sample fluid that is inserted on a comparative injection syringe.

\section{B. Block diagram and Flowchart}

When the switch is ON, the power supply or battery will supply voltage to the entire circuit. And loadcell sensor can directly read the weight contained on the container to calibrate or at the same time the taring process, to reduce the previous weight already contained in the container or the weight of the blood bag, after that the selection of the desired volume setting can be done either $250 \mathrm{ml}, 350 \mathrm{ml}$, or $450 \mathrm{ml}$. after selecting the 
settings and start the shaking process will work and the sensor will read the incoming sample volume. The motor shake will stop, and the buzzer will automatically sound when there is no increase in volume by 20 milliliters for 1 minute as an indication of obstacles. And can be restarted to continue the transfuse process until it reaches the specified volume, then the rocking motor will stop, the clamp motor will function, and the buzzer alarm will light up as an indication that the process of the transfuse has been completed

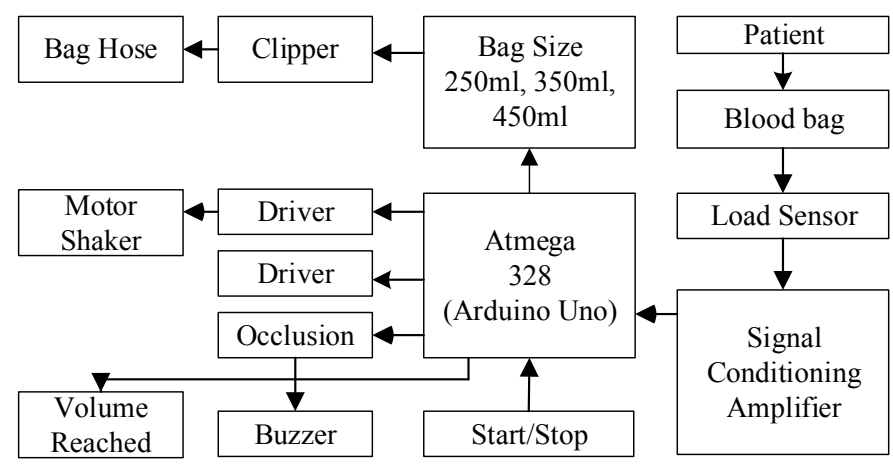

Fig. 1. A block diagram of Blood Collection Mixer

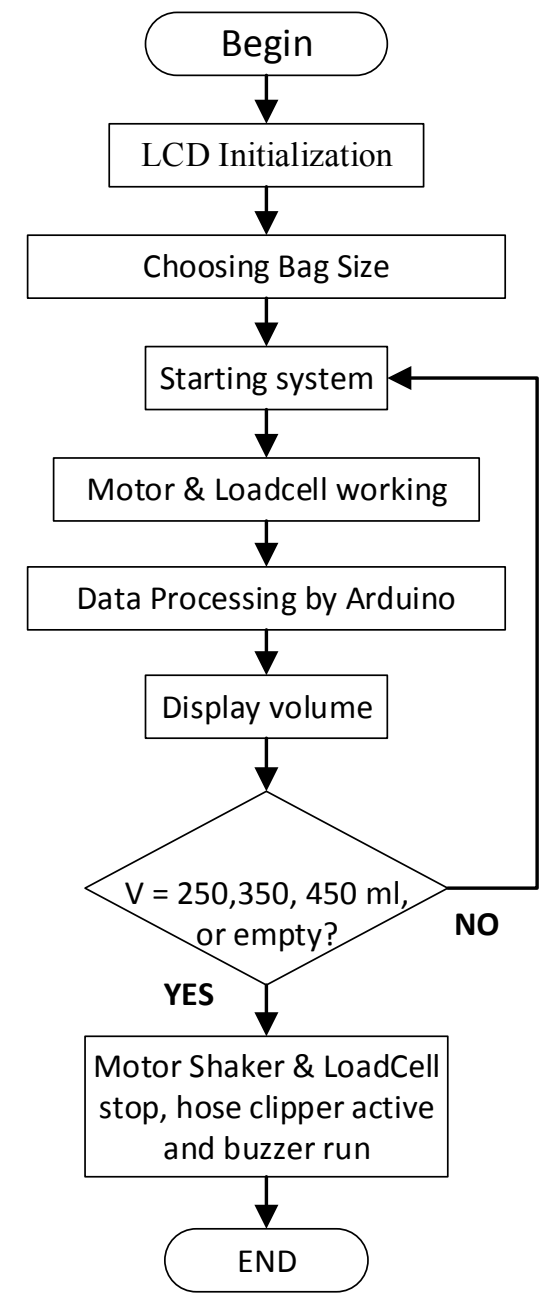

Fig. 2. The Flowchart Program Arduino

\section{The Flowchart}

The Arduino program runs like a Figure flow chart. 2. The program starts from the LCD initialization display and selects the settings for the pocket volume, then can be started pressing the start button then loadcell and the motor shake will work, then it will stop automatically if there is an obstacle, and can be resumed after pressing the start button again. After the bag size selection has reached the volume setting, the shake motor will stop, the buzzer alarm, and the clamping motor will be active. After doing the stop button, then the whole system will return to the initial position or standby.

D. Circuit

1) Hx-711 Amplifier 


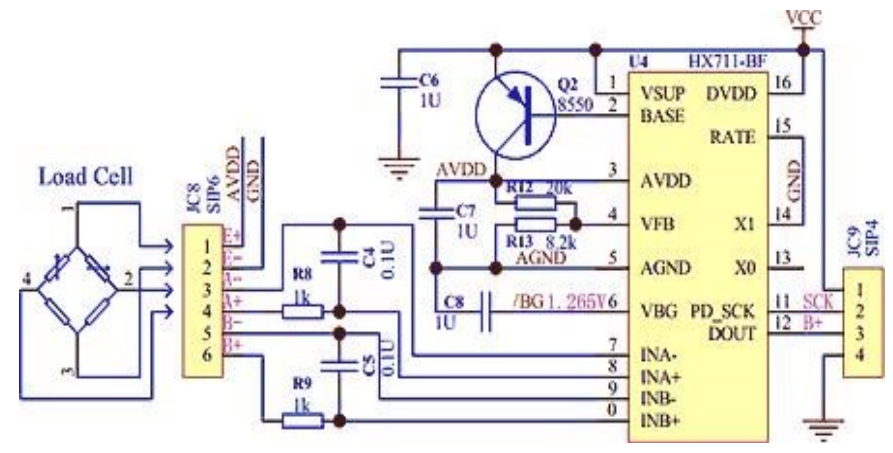

Fig. 3. instrumentation amplifier

The Hx711 Amplifier circuit, as shown above, gets input from a load cell sensor. And strengthen the input so that Arduino Uno can read it.

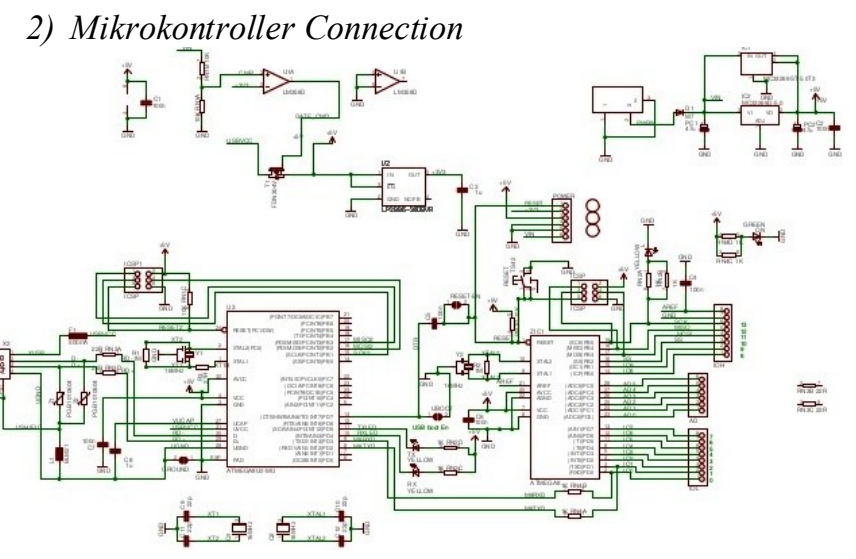

Fig. 4. A series of Arduino Uno Atmega 328 minimum system modules

The Output Load Cell powered by the Hx711 Amplifier is then entered into Arduino which is then processed to run the next command.

\section{3) Overall Connection}

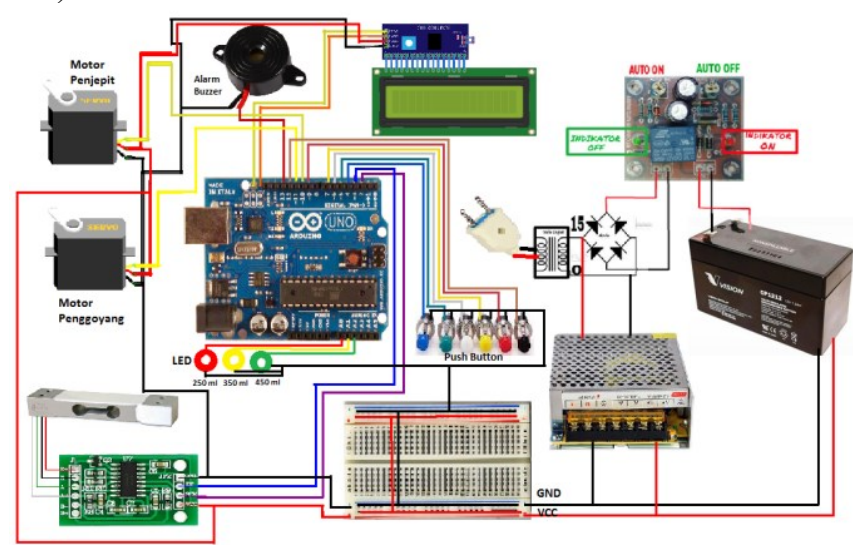

Fig. 5. Overall Connection of Circuits
The output of the Loadcell sensor, which is powered by the Hx-711 module, is then processed on Arduino, which is then displayed on the LCD to show the reading results. And put on the servo motor and buzzer alarm to run every condition as instructed.

\section{RESULT}

In this study, a test using an injection syringe was used to adjust how much volume was entered with the results displayed on the LCD reading.

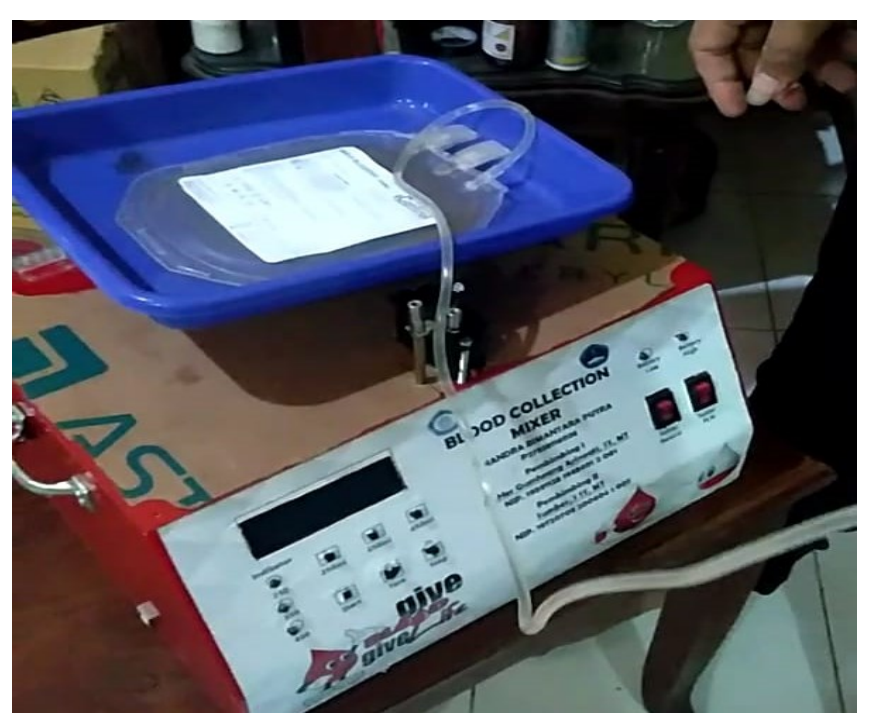

Fig. 6. Blood Collection Monitor

\section{1) Desain Blood Collection Monitor}

Design drawing tools can be seen in Figs. 6. Blood bags filled with liquid blood samples are then placed in an available container. Then you can choose three sizes of the specified bag volume, and the measurement results can be seen on the LCD.

\section{2) Arduino Program Results}

The Arduino listing program consists of the initial initialization program for all hardware and components shown in Listing 1 program, the program for the mathematical formula reading the sensor and conditioning the initial conditions before being given the load indicated in Listing program 2, the program for the command in each bag selection shown in Listing program 3.

Listing program 1. Initial initialization program for all hardware and components. 


\section{LOOP}

motorServo1.attach (11);

motorServo2.attach (10);

pinMode(PB250,INPUT);

pinMode(PB350,INPUT);

pinMode(PB450,INPUT);

pinMode(LED250,OUTPUT);

pinMode(LED350,OUTPUT);

pinMode(LED450,OUTPUT);

pinMode(selenoid,OUTPUT);

pinMode(alarm,OUTPUT);

digitalWrite(alarm,LOW);

pinMode(Start,INPUT);

pinMode(Stop,INPUT);

Serial.begin $(9600)$;

Serial.println("Memulai Program Kalibrasi");

Serial.println("Pastikan tidak ada beban diatas sensor");

delay (5000);

scale.set_scale();

scale.tare();

long zero_factor $=$ scale.read_average();

Serial.print("Zero factor: ");

Serial.println(zero_factor);

lcd.begin(16, 2); // begins connection to the LCD module lcd.backlight(); // turns on the backlight

FOR (int thisReading $=0$; thisReading $<$ numReadings;

thisReading ++ )

readings[thisReading] $=0$;

\section{ENDFOR}

ENDLOOP

Listing program 2. Program for mathematical formulas for sensor readings and conditions for initial conditions before being loaded

\section{LOOP}

// subtract the last reading:

total $=$ total - readings $[$ readIndex $]$;

$/ /$ read from the sensor:

readings $[$ readIndex $]=$ scale.get_units();

// add the reading to the total:

total $=$ total + readings [readIndex $]$;

// advance to the next position in the array:

readIndex $=$ readIndex +1 ;

// if we're at the end of the array...

IF (readIndex $>=$ numReadings) THEN

// ...wrap around to the beginning:

readIndex $=0$;

\section{ENDIF}

// calculate the average:

average $=$ total $/$ numReadings $* 10$;

scale.set_scale(calibration_factor);

Serial.print("volume: ");

Serial.print(average);

Serial.println(" mili");

IF $($ average $<0) / /$ THEN

average $=0$;

\section{ENDIF}

IF $($ digitalRead(PBTer $)==$ HIGH) THEN

ter=average;

lcd.clear();

lcd.setCursor $(0,0)$; // set cursor to first row lcd.print("WAITING FOR ZERO POINT"); delay(1500);

\section{ENDIF}

average $=$ average-ter;

waktu=millis()-waktureset;//

IF (waktu>100) THEN

lcd.clear();

lcd.print("Volume :"); // print out to LCD

if(kunci==1) THEN

lcd.print("250 ml"); // print out to LCD

ENDIF

IF (kunci==2) THEN

lcd.print("350 ml"); // print out to LCD

ENDIF

IF (kunci==3) THEN

lcd.print("450 ml"); // print out to LCD

ENDIF

lcd.setCursor $(0,1)$; // set cursor to secon row

lcd.print(average); //

waktureset $=$ millis();

ENDIF 


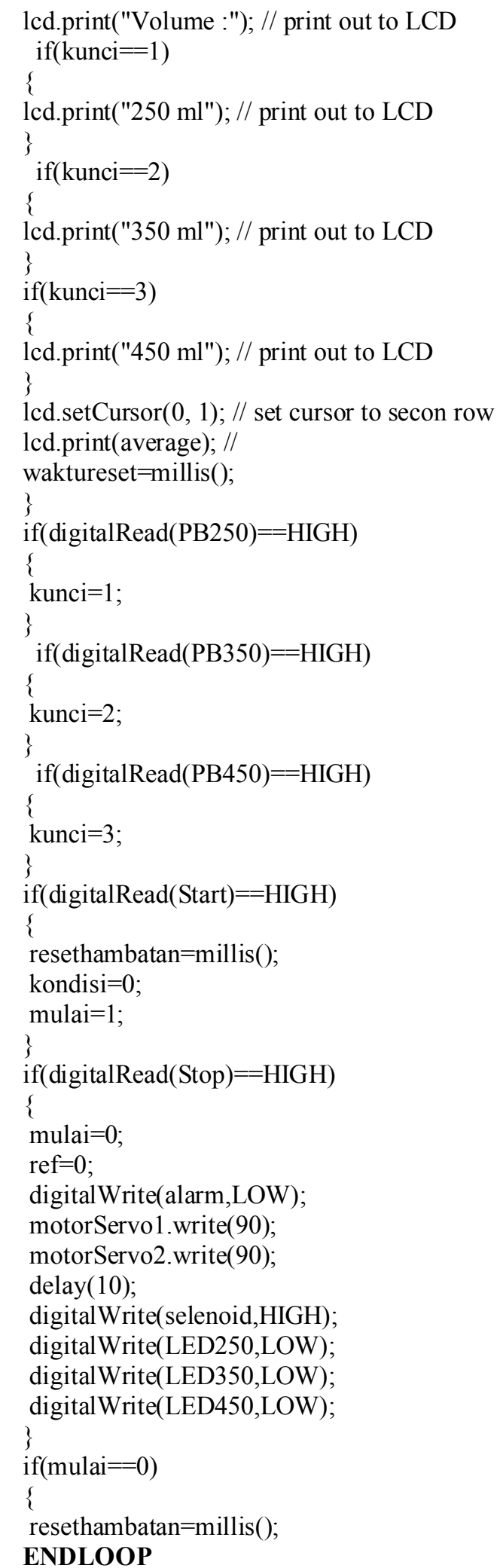

Listing program 3. This program is for commands in each bag selection, in the example of this program is a program for $350 \mathrm{ml}$ bag settings

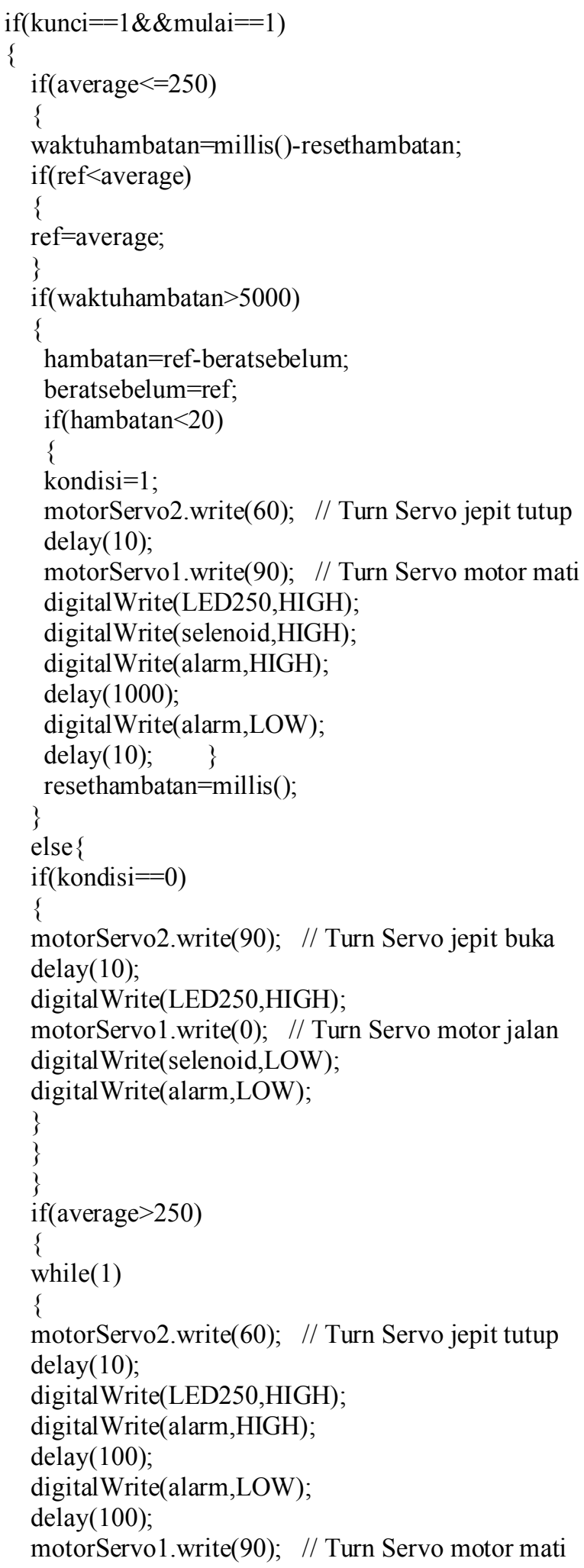


TABLE IV. MEASURING WHEN THERE IS A VOLUME OF $450 \mathrm{ML}$

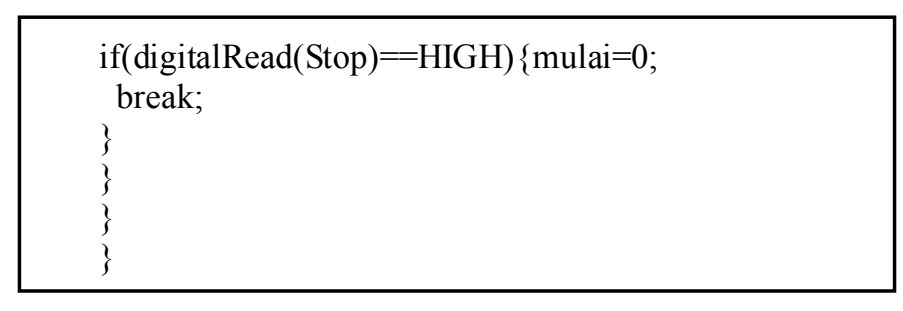

3) The Results of the Voltage Measurement at the Weight Sensor Output

Here is a measurement of the weight sensor voltage by measuring 5 times on each the choice of each volume setting.

TABLE I. MEASUREMENT WHEN THERE IS NO VOLUME

\begin{tabular}{ccc}
\hline Data & $\begin{array}{c}\text { In Serial Monitor } \\
\text { (desimal) }\end{array}$ & $\begin{array}{c}\text { V Load Cell } \\
\text { (Load Cell Sensor Output) }\end{array}$ \\
\hline 1 & 0.00 & $2 \mathrm{mV}$ \\
\hline 2 & 0.00 & $2 \mathrm{mV}$ \\
\hline 3 & 0.00 & $2 \mathrm{mV}$ \\
\hline 4 & 0.00 & $2 \mathrm{mV}$ \\
\hline 5 & 0.00 & $2 \mathrm{mV}$ \\
\hline
\end{tabular}

The table above shows that 5 times the test point has been measured on the module. In the first measurement when there is no load, up to 5 times the measured voltage at the Load Cell sensor output of $2 \mathrm{mV}$.

TABLE II. MEASURING WHEN THERE IS A VOLUME OF $250 \mathrm{ML}$

\begin{tabular}{ccc}
\hline Data & $\begin{array}{c}\text { In Serial Monitor } \\
\text { (desimal) }\end{array}$ & $\begin{array}{c}\text { V Load Cell } \\
\text { (Load Cell Sensor Output) }\end{array}$ \\
\hline 1 & 250.00 & $7 \mathrm{mV}$ \\
\hline 2 & 250.00 & $7 \mathrm{mV}$ \\
\hline 3 & 250.00 & $7 \mathrm{mV}$ \\
\hline 4 & 250.00 & $7 \mathrm{mV}$ \\
\hline 5 & 250.00 & $7 \mathrm{mV}$ \\
\hline
\end{tabular}

The table above shows that 5 times the test point has been measured on the module. In the first measurement when there is a $250 \mathrm{ml}$ volume, up to 5 times the measured voltage measured at the Load Cell sensor output of $7 \mathrm{mV}$.

TABLE III. MEASURING WHEN THERE IS A VOLUME OF 350 ML

\begin{tabular}{ccc}
\hline Data & $\begin{array}{c}\text { In Serial Monitor } \\
\text { (desimal) }\end{array}$ & $\begin{array}{c}\text { V Load Cell } \\
\text { (Load Cell Sensor Output) }\end{array}$ \\
\hline 1 & 350.00 & $9 \mathrm{mV}$ \\
\hline 2 & 350.00 & $9 \mathrm{mV}$ \\
\hline 3 & 350.00 & $9 \mathrm{mV}$ \\
\hline 4 & 350.00 & $9 \mathrm{mV}$ \\
\hline 5 & 350.00 & $9 \mathrm{mV}$ \\
\hline
\end{tabular}

The table above shows that 5 times the test point has been measured on the module. In the first measurement when there is a $350 \mathrm{ml}$ volume, up to 5 times the measured voltage measured at the Load Cell sensor output of $9 \mathrm{mV}$.

\begin{tabular}{ccc}
\hline Data & $\begin{array}{c}\text { In Serial Monitor } \\
\text { (decimal) }\end{array}$ & $\begin{array}{c}\text { V Load Cell } \\
\text { (Load Cell Sensor Output) }\end{array}$ \\
\hline 1 & 450.00 & $11 \mathrm{mV}$ \\
\hline 2 & 450.00 & $11 \mathrm{mV}$ \\
\hline 3 & 450.00 & $11 \mathrm{mV}$ \\
\hline 4 & 450.00 & $11 \mathrm{mV}$ \\
\hline 5 & 450.00 & $11 \mathrm{mV}$ \\
\hline
\end{tabular}

The table above shows that five times the test point has been measured on the module. In the first measurement, when there is a $450 \mathrm{ml}$ volume, up to 5 times the measured voltage measured at the Load Cell sensor output of $11 \mathrm{mV}$.

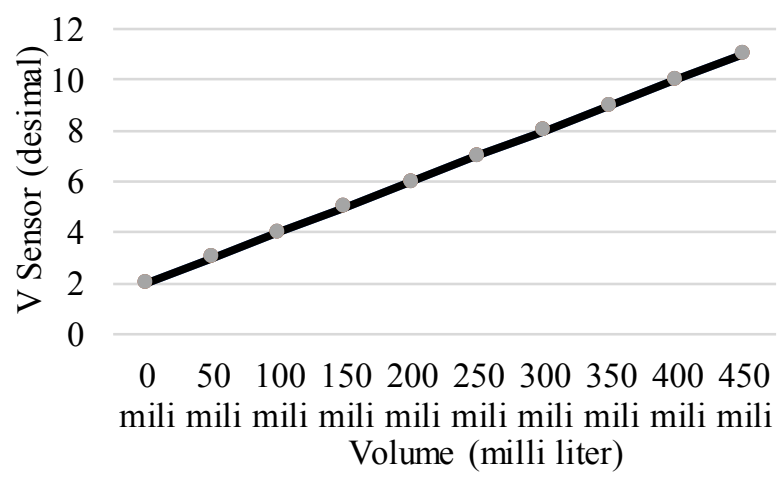

Fig. 7. Graph of increase in sensor voltage by volume

The graph shows the increase between the voltage on the sensor and the volume on the liquid sample read shows a linear increase.

\section{4) Measurement by comparison}

TABLE V. MEASUREMENT OF THE SENSOR READINGS WITH A COMPARISON

\begin{tabular}{ccc}
\hline Volume & Measured Volume & difference in \\
measured \\
volume
\end{tabular}

Setting

$(\mathrm{ml})$

\begin{tabular}{ccccccc}
\cline { 2 - 6 } & $\mathrm{X} 1$ & $\mathrm{X} 2$ & $\mathrm{X} 3$ & $\mathrm{X} 4$ & $\mathrm{X} 5$ & \\
\hline $0 \mathrm{ml}$ & 0 & 0 & 0 & 0 & 0 & 0 \\
\hline $50 \mathrm{ml}$ & 50 & 50 & 50 & 50 & 50 & 0 \\
\hline $100 \mathrm{ml}$ & 100 & 100 & 100 & 100 & 100 & 0 \\
\hline $150 \mathrm{ml}$ & 150 & 150 & 150 & 150 & 150 & 0 \\
\hline $200 \mathrm{ml}$ & 200 & 200 & 200 & 200 & 200 & 0 \\
\hline $250 \mathrm{ml}$ & 250 & 250 & 250 & 250 & 250 & 0 \\
\hline $300 \mathrm{ml}$ & 300 & 300 & 300 & 300 & 300 & 0 \\
\hline $350 \mathrm{ml}$ & 350 & 350 & 350 & 350 & 350 & 0
\end{tabular}


TABLE VI. (CONTINUED)

\begin{tabular}{lllllll}
\hline $400 \mathrm{ml}$ & 400 & 400 & 400 & 400 & 400 & 0 \\
\hline $450 \mathrm{ml}$ & 450 & 450 & 450 & 450 & 450 & 0
\end{tabular}

The table above shows the comparison between the amount of volume in the bag and the volume at the comparison. By measuring every $50 \mathrm{ml}$ of volume and making five measurements, the same results are obtained, or it is no different for each measured blood volume.

TABLE VII. MEASUREMENT ERROR FROM THE BLOOD COLLECTION MONITOR

\begin{tabular}{ccc}
\hline No & Volume $(\mathrm{mL})$ & Error $(\%)$ \\
\hline 1 & 0 & 0 \\
2 & 250 & 0 \\
3 & 350 & 0 \\
4 & 450 & 0
\end{tabular}

Following is a table of error percentages for each volume setting specified

TABLE VIII. OVERALL MEASUREMENT RESULTS

\begin{tabular}{ccccc}
\hline Volume & $\begin{array}{c}0 \\
(\mathrm{ml})\end{array}$ & $\begin{array}{c}250 \\
(\mathrm{ml})\end{array}$ & $\begin{array}{c}350 \\
(\mathrm{ml})\end{array}$ & $\begin{array}{c}450 \\
(\mathrm{ml})\end{array}$ \\
\hline $\bar{x}$ & 0 & 0 & 0 & 0 \\
\hline Deviation & 0 & 0 & 0 & 0 \\
\hline $\mathrm{SD}$ & 0 & 0 & 0 & 0 \\
\hline $\mathrm{UA}$ & 0 & 0 & 0 & 0 \\
\hline$\%$ Error & $0 \%$ & $0 \%$ & $0 \%$ & $0 \%$ \\
\hline
\end{tabular}

Following are the results obtained from the total overall calculation for each volume set in the module.

\section{Discussion}

Based on the measurement of the load cell weight sensor and the Hx-711 module, it produces a linear output at each incoming volume increase with an increase in voltage on the weight sensor. By measuring five times for each $50 \mathrm{ml}$ increment that starts when there is no weight or 0 milliliters i.e., two $\mathrm{mV}$ to $450 \mathrm{ml}$, i.e., $11 \mathrm{mV}$. The result of the whole process of doing this module is the calculation results obtained from the measurement of all blood bag sizes with an average / $\overline{\mathrm{x}}$ : 0 , deviation: 0, Standard Deviation / SD: 0, Uncertainty / UA: 0, \% error: 0 . So that it can be concluded this tool can be used properly. And the results of this study obtained a more precise value than previous studies that have been made because in this study, there were no errors nor differences in the volume displayed on the instrument, with the actual volume.

\section{Conclusion}

This research shows the development of a Blood Collection Monitor Tool to be able to take readings at a more accurate volume, by displaying the reading results every $10 \mathrm{ml}$ on increasing the volume and displaying it on the LCD. And equipped with an obstacle indicator if there is no increase in volume by $20 \mathrm{ml}$ for 1 minute. This research was built on Arduino Atmega 328 microcontroller and supported by several supporting components and hardware to be able to work optimally. So that this study can be used as a tool for blood transfusion, but it is hoped that in the future this research can be developed by being able to read blood volume in every milliliters of volume increase so that users can find out more in detail every time there is an increase in blood volume.

\section{REFERENCE}

[1] U. Charoen-in and W. Pantasri, "Development of a donated blood shaking machine," pp. 695-701.

[2] S. C. Gupte, "Automation in Blood Centre : Its impact on Blood Safety," vol. 9, no. April, 2015.

[3] N. S. Gerstein, "Regarding Epidural Catheters and DrugEluting Stents," J. Cardiothorac. Vasc. Anesth., vol. 22, no. 5, pp. 800-801, 2008.

[4] T. Is, T. H. E. Final, and D. Version, "EFLM Recommendation for venous blood sampling," no. October, 2017.

[5] R. C. Dara, A. K. Tiwari, D. Arora, G. Rawat, and V. Raina, "CAPA analysis of clotted red cell unit detected during leukodepletion process: Importance of quality check on blood collection monitors," Asian J. Transfus. Sci., vol. 9, no. 2, pp. 217-218, 2015.

[6] S. Shastry and S. Das, "Volume 10 Issue 1," no. January, 2016.

[7] P. E. F. Rosenbaum and I. C. R. Valeri, "United States Patent ( 19) 11 Patent Number:," no. 19, 1989. 